\title{
A relação do povo indígena Bororo com os animais e a influência em suas práticas culturais e sociais
}

\author{
The relation of Bororo indigenous people with animals and \\ how it influences their cultural and social practices
}

\author{
Cézar Amin Rondon ${ }^{1}$ \\ Marcelo Franco Leão ${ }^{2}$
}

DOI: http://dx.doi.org/10.20435/tellus.v18i36.507

\begin{abstract}
Resumo: A cultura dos povos indígenas é rica e caracteriza-se pela intensa relação com a natureza. Nesse aspecto, a etnia Bororo desenvolve uma relação estreita com os animais, pois, dessa convivência, derivam vivências, ritos e práticas socioculturais. O presente estudo tem por objetivo descrever essa relação e sua influência nas práticas culturais e sociais desse povo tradicional, definindo-se, assim, como um estudo etnográfico, descritivo e exploratório, cujo desenvolvimento ocorreu nos anos de 2014 e 2015 . O estudo contou com relatos de um consultor nativo, residente na Terra Indígena de Tadarimana, localizada no município de Rondonópolis, MT. Apresenta a descrição de rituais tradicionais, a divisão social feita pelo povo Bororo, desde os antepassados, a qual se baseia nos animais para determinar cada Clã e Sub Clã, e elenca os números de animais particulares a cada Sub Clã. Essas divisões servem também para estabelecer os pertences de cada Sub Clã e sua posição na comunidade. Fica evidente o cuidado e respeito com o meio em que vivem, pois é a natureza que fornece os recursos para subsistência. Registrar as regras, costumes e organização social é uma forma de perpetuar os costumes, geralmente restritos à oralidade, que fazem dos Bororo um povo que vive o místico e o real, na busca pelo equilíbrio entre o homem e a natureza.
\end{abstract}

Palavras-chave: organização social; costumes tradicionais; natureza; povo Bororo.

\begin{abstract}
The indigenous peoples have a rich culture that is characterized by its close relation with nature. Within this aspect, the Bororo ethnicity has developed a narrow relation with animals, from which coexistence experiences, rites and sociocultural practices derive. The purpose of this study is to describe that relation and its influence in this traditional people's social and cultural practices,
\end{abstract}

${ }^{1}$ Universidade do Estado de Mato Grosso (UFMT), Rondonópolis, Mato Grosso, Brasil.

${ }^{2}$ Universidade Federal do Rio Grande do Sul (UFGRS), Porto Alegre, Rio Grande do Sul, Brasil.

Tellus, Campo Grande, MS, ano 18, n. 36, p. 123-152, maio/ago. 2018 
thus, by definition, being an ethnographic, descriptive and exploratory study that was developed in 2014 and 2015. It is supported by statements from a native consultant who resides in the Tadamarimana Indigenous Land located in the municipality of Rondonópolis, MT. It presents the description of traditional rituals, the social division accomplished by the Bororo people since their ancestors that is based on animals to determine each Clan and Sub-Clan, and it lists the numbers of animals particular to each Sub-Clan. Such divisions also serve the purpose of establishing each Sub-Clan's belongings and its position within the community. Care and respect with the environment they inhabit are brought to evidence, since it is nature that provides the resources for their subsistence. Recording rules, costumes and social organization is a way to perpetuate the costumes, usually restricted to orality, results in the Bororo being a people who live a mystical and real life in pursuit of a balance between man and nature.

Keywords: social organization; traditional costumes; nature; Bororo peoples.

\section{INTRODUÇÃO}

O povo brasileiro é constituído pela interação entre as três matrizes de sua formação, a saber: os indígenas, que aqui habitavam, os colonizadores portugueses e os negros que foram trazidos para o país na condição de escravos (RIBEIRO, 1995). Essa diversidade étnica e cultural é resultado desse processo de colonização e ocupação nas diversas regiões do território nacional.

No estado de Mato Grosso, segundo Grando (2016), atualmente vivem diversos povos indígenas de 43 etnias conhecidas. Contudo ocorreram muitos conflitos ao longo do processo de ocupação que permanecem até os dias atuais nessa região. Esses conflitos entre os diferentes grupos sociais e étnicos influenciaram negativamente no modo de viver de muitos desses povos indígenas.

O que se percebe é que os indígenas, que eram ocupantes de uma vasta região e tinham uma forte riqueza cultural, passaram por diferentes processos históricos de mudança. De acordo com Januário (2004), muitos desses povos se descaracterizaram depois do contato com o não indígena, e alguns deles até deixaram de existir aos olhos da sociedade envolvente. Ainda segundo o autor, a situação imposta pela cultura dominante suprime muitos dos elementos culturais e interfere diretamente na organização social desses povos, sem contar com a tentativa de integração sociocultural para fazer sucumbir a identidade dos povos tradicionais, cujos descendentes são considerados como bugres, e não mais como índios. 
Um aspecto preocupante a ser considerado é que as tradições desses povos indígenas são repassadas pela oralidade, no dia a dia, nas suas manifestações culturais. Até há pouco tempo, entre os indígenas Bororo, por exemplo, os conhecimentos tradicionais eram repassados de forma oral, na casa central (Baito).

Contudo, por mais que uma cultura seja resistente, o dinamismo imposto pela sociedade envolvente faz com que esse método de transmissão de saberes se torne fragilizado. Para evitar que esses importantes conhecimentos sobre os aspectos culturais caiam no esquecimento, é preciso reforçar o registro de memórias por meio da transmissão de saberes pela oralidade, tão importante na sociedade indígena, bem como pelo registro escrito, fator esse que motivou a realização do presente estudo.

Assim, o indicado é que cada povo registre os elementos que constituem sua cultura, para assim contribuir com a comunidade (papel social) e com a comunidade escolar (como fonte de pesquisas escolares). Dessa forma, acredita-se que uma pesquisa como essa tenha um papel muito importante no meio social indígena e, posteriormente, para a escola, pois o registro das memórias culturais servirá tanto para a sociedade quanto para a comunidade escolar.

Por sua vez, o povo Bororo ainda conserva elementos importantes de sua cultura: a língua, a arte plumária, o funeral rico em termos rituais e outras práticas sociais e religiosas. Os Bororo são exímios artistas, utilizam penas de aves na confecção de objetos que, além de belos, caracterizam a hierarquia social na etnia, a exemplo do pariko 'diademas plumárias' que marca posição hierárquica na sociedade bororo.

Cabe aqui registrar que o pesquisador é indígena e pertencente à etnia Bororo. Na comunidade em que vive, as casas ainda são de forma tradicional, porém já saíram as casas do grande círculo ao redor da casa central. A continuidade dos valores culturais depende da relação dos indígenas com o ambiente natural que ofereça condições de materialização e reprodução da cultura Bororo.

A cultura Bororo é riquíssima em ritos e cosmologia; para quem faz uma observação mais profunda se percebe que são inúmeras simbologias que estão presentes nos rituais Bororo. O povo Bororo tem a sua visão cosmológica de mundo, cultua a parte espiritual do ser humano, visto que o ápice de sua manifestação cultural está centrado no Funeral (SOUZA, 2014). 
Segundo a autora supracitada, nessa manifestação cultural, são utilizados alguns recursos que a natureza oferece, tais como: o Kidoguru³, esteiras (feitas da palha de certo tipo de pé de coco), Nonogo 4 (confeccionado pelas mulheres), Pariko $^{5}$ (feito de penas de arara amarela e vermelha), Pana (instrumento de sopro que é confeccionado com as cabaças) e Ika (instrumento de sopro que é confeccionado com um certo tipo de madeira), entre outros. Conforme é possível perceber, é forte a relação do povo Bororo com a natureza, o que possibilitou o exercício de uma simbologia rica e cheia de representações.

Outro aspecto a ser considerado é que são poucos os registros publicados especificamente sobre a cultura Bororo em periódicos nacionais e internacionais. Nessas últimas duas décadas, foram encontrados apenas dois estudos. Um deles relatou a concepção de uma exposição museográfica da Cultura Bororo para evidenciar os elementos simbólicos dessa etnia, rica em cultura e diversidade (CALARGE, 2013). O outro refletiu sobre o olhar das crianças Bororo sobre a cultura por meio de desenhos infantis e representações, estudo esse que foi recentemente publicado (CALARGE, 2017).

Dentre tantos outros aspectos que constituem a cultura Bororo e que ainda precisam ser investigados, o elemento escolhido para ser registrado envolve a relação desse povo com os animais. Por meio deste estudo, espera-se registrar os ensinamentos de outrora, que foram ensinados pelos nossos antepassados sobre o significado dos animais, para a cultura e organização social do povo Bororo.

Diante do exposto, o presente estudo tem como objetivo descrever a relação existente entre o povo indígena Bororo e os animais, com o intuito de identificar a influência dessa relação nas vivências, ritos, práticas sociais e culturais desse povo tradicional mato-grossense.

Cabe dizer que este estudo é um recorte do Trabalho de Conclusão de Curso de Licenciatura em Ciências Matemáticas e da Natureza, apresentado para a Faculdade Intercultural Indígena da Universidade do Estado de Mato Grosso (UNEMAT), e cuja defesa ocorreu no ano de 2016.

\footnotetext{
${ }^{3}$ Resina que é retirada de um pé de vegetal que fica nas beiras de córregos.

${ }^{4}$ Bola de urucum confeccionada pelas mulheres Bororo para utilização nas pinturas corporais dos Bororo.

${ }^{5}$ Cocar feito pelos Bororo utilizado para a maioria dos rituais, estes estão sempre presentes nas funções culturais deste Povo.
} 


\section{REFLEXÕES TEÓRICAS}

O povo indígena Bororo, palavra cujo significado é pátio da aldeia, se autodenomina Boe. São indígenas que vivem no Estado de Mato Grosso, falantes de uma língua pertencente ao tronco linguístico Macro-Jê (SOUZA; PAGLIARO; SANTOS, 2009). A palavra Bakaru, para os Bororo, é a especificação de toda a sua cosmologia sociocultural como: origem, história, explicação de tudo, é o norteador dos Bororo.

Segundo Albisetti e Venturelli (1962), o Bakaru-Boe, quer dizer Boe, índios bororo e Akaru, narração. As lendas, contos, fábulas, enfim, a tradição oral como um todo é transmitida fielmente, de geração em geração, pela oralidade. Todos esses costumes ensinados têm uma finalidade: explicar fenômenos naturais, justificar a existência de certos seres, estabelecer a origem de tradições e ornamentos desse povo que se autodenomina "Böe" (SOUZA, 2014).

Atualmente, os Bororo não são mais nômades como antigamente, já se situam em aldeias fixas desde vários anos, visto que se encontram privados de andar por outros lugares pela redução de suas terras, pois vivem em lugares restritos. Segundo Souza, Pagliaro e Santos (2009), os Bororo focalizados neste estudo vivem na Terra Indígena (TI) de Tadarimana, que se encontra a jusante das bacias hidrográficas dos rios Jurigue e Tadarimana, ambos afluentes do rio Vermelho. A localização da TI de Tadarimana, uma entre tantas localidades em que vivem os Bororo, está ilustrada na Figura 1. 
Figura 1 - Localização da TI Tadarimana onde se efetuou este estudo

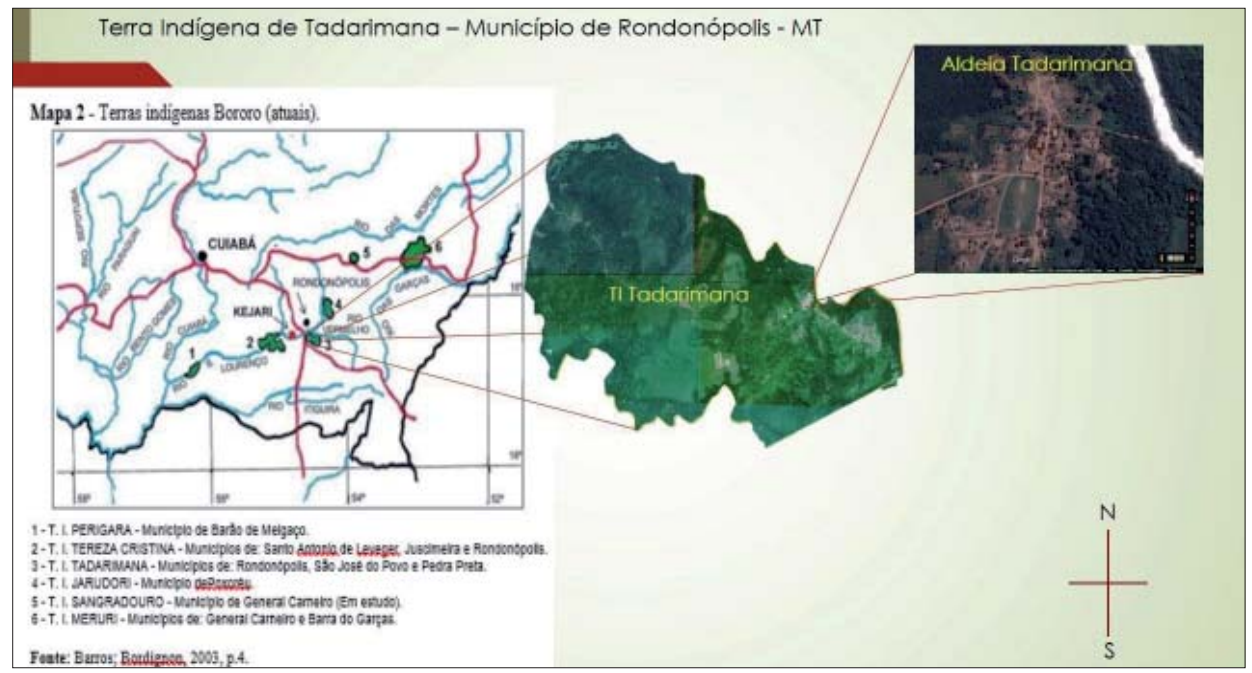

Fonte: Adaptado de Barros e Bordignon (2003).

A área territorial de abrangência da etnia Bororo no município de Rondonópolis, faz limite com os rios: Vermelho, Tadarimana e Jurigue.

[...] A reserva compreende uma área de 9.785 hectares no município de Rondonópolis até as proximidades do município de Pedra Preta, contando com população reduzida de aproximadamente 200 índios distribuídos nas aldeias: Jurigue, Praião, Pobore, Paulista e Aldeia Central Tadarimana. Esse povo é caracterizado por uma riqueza de organização social e de vida cerimonial. A sociedade indígena Bororo, em seus aspectos físicos e culturais é um importante patrimônio cultural. (ISAAC, 2004).

Esse levantamento populacional, feito por Isaac (2004), já sofreu algumas alterações numéricas de acordo com o censo ocorrido em 2012, como também algumas alterações no número de aldeias dentro da TI Tadarimana que são: Aldeia Tadarimana ${ }^{6}$ (a forma correta e Tadari Umana), Jurigue ${ }^{7}$, Pobore $^{8}$, Praião ${ }^{9}$, Pobo

\footnotetext{
${ }^{6}$ Aldeia fica às margens do rio Tadarimana.

${ }^{7}$ Aldeia que fica nas proximidades do rio Jurigue e, na língua dos Bororo, o nome correto é Jerige que quer dizer lenha.

${ }^{8}$ Aldeia que fica às margens do rio Vermelho, e tem como significado água em abundância.

${ }^{9}$ Nome dado à aldeia que fica às margens do rio Tadarimana que na época da seca tinha uma praia muito grande onde os Bororo se banham, o nome da língua materna de Praião é kugaru, que quer dizer praia.
} 
Jari $^{10}$, Noidoguru $^{11}$ e Jatugo Iguru ${ }^{12}$.

Em 1996, a população total Bororo em Mato Grosso, compreendendo as aldeias Meruri, Garças e Morada dos Bororo, era de 1.648 pessoas (SOUZA; PAGLIARO; SANTOS, 2009). O quadro populacional da TI Tadarimana em que ocorreu a investigação é de 442 habitantes, sendo dados do censo realizado em 2012 (SOUZA, 2014).

Atualmente, a comunidade conta com 450 pessoas aproximadamente, as casas ainda são tradicionais, porém a organização espacial das casas foi se alterando com o tempo, ou seja, as casas foram se espalhando, não seguindo as suas posições de origem. Fora do espaço tradicional da aldeia, temos o posto de saúde e a escola (ISAAC, 2004).

Segundo os estudos antropológicos de Calarge (2013), o povo Bororo é organizado socialmente e territorialmente em duas metades, os Tugarege e os Ecerae. Cada uma dessas metades, ou clãs, é subdividida em quatro sub clãs cada. Os Tugarege são o grupo social da metade exogâmica que moram na parte sul da aldeia circular, sendo a forma plural de Tugare $($ Tugo $=$ Flecha + Are $=$ Mestre Dono, mas sem domínio de posse), e a forma feminina correspondente seria Tugareredo. Por sua vez, os Ecerae são os moradores da metade norte do círculo da aldeia, sendo o plural de Ecerae, e o feminino correspondente Ecerare.

Na metade Ecerae, estão os clãs denominados: Baado Jebage 'os construtores da aldeia', Kie 'antas', Bokodori Ecerae 'os tatu canastra' e Bakoro Ecerae 'espírito Bakoro'. Na metade Tugarege, estão os clãs: Aroroe 'as larvas', Iwagududoge 'as gralhas', Apiborege 'os donos da palmeira' e Paiwoe 'os bugios'. Essa maneira de organização social pode ser observada na Figura 2.

\footnotetext{
${ }^{10}$ Nome dado à aldeia pelo fato de ela estar em um lugar que tem um olho d'água.

${ }^{11}$ Nome da aldeia pelo fato de ela estar em um lugar que tem muito pé de palmeira, fica perto do antigo Posto da Funai, com famílias de Bororo vindo da Aldeia Sangradouro, que fica à beira da BR 070.

12 Nome da aldeia se refere ao fato de ela estar num lugar que tem muito cajazinho do mato.
} 
Figura 2 - Organização social e espacial do povo Bororo

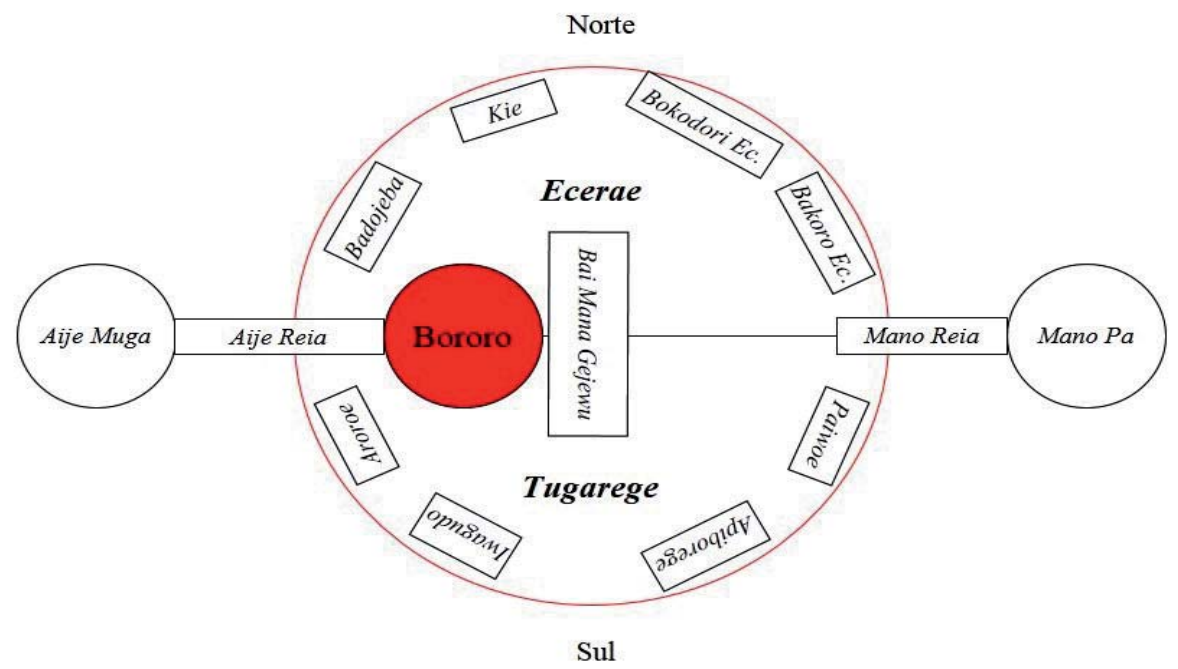

Fonte: Elaborado pelo autor indígena (2016).

Conforme é possível observar na Figura 2, no centro da aldeia, fica o Bai Mana Gejewu, Aroe Wai ou Baito 'casa central onde acontecem as funções culturais'; posicionado a oeste dessa casa, fica o Bororo 'pátio', de onde se vai, por um caminho a oeste, o Aije Reia 'caminho destinado onde ficará os espíritos das águas', até uma clareira, o Aije Muga 'praça do Aije'. Aije é um ser sobrenatural com o qual os Bororo se relacionam, conhecido como Espírito das águas. Do lado leste, temos o Mano Reia 'caminho do mano' e, no extremo desse caminho, temos o Mano Pa 'lugar onde se arruma o mano para as competições entre os dois grandes clãs Ecerae e Tugarege' (SOUZA, 2014).

As partes de um ritual são vivenciadas de forma intensa, é a relação para o Bororo do material e o espiritual, ou seja, o ser físico e o cosmológico estão em profunda harmonia, e essa relação é respeitada pelos Bororo. O ápice dos rituais desse povo ocorre durante o Funeral Bororo, que pode levar até três meses de luto numa aldeia Bororo. Os valores humanos, o respeito e o companheirismo entre eles, são vistos nesses momentos dos rituais, levados a efeito durante o luto da família (OCHOA CAMARGO, 2010). 
Estão presentes também outros rituais como o Barogo Ukedodu, 'festa do couro da onça', que seria quando um Bororo mata uma onça e se faz este ritual de vingança de um finado, que os Bororo chamam de "Boe Emoriae". O bokwa doge, 'festa do peixe', é um ritual de pesca de alegria, no qual todas as mulheres são contempladas; em contrapartida elas mandam oferendas, parte do pescado e o Boe Kugu (mingau), feito no caldo do peixe, para o Baito, que significa casa central (SOUZA, 2014).

Ainda segundo a autora supracitada, o Kuiada Paru, 'festa do milho', se refere ao ritual do milho. Os Bororo se alegram quando tem o milho plantado, aí se tem a previsão de que, depois de uns quatro meses, se tem o ritual do kuiada paru, e também esse ritual envolve as almas que os Bororo chamam de Aroe.

O nascer de uma criança Bororo é motivo de alegria para toda a família, em especial à família materna, ainda mais se a criança for do sexo feminino, visto que será ela que perpetuará os Bororo do seu clã e sub clã e fortalecerá ainda mais o trabalho masculino, pois o futuro esposo se deslocará para a casa dela após o casamento. A sociedade Bororo é matrilinear, os filhos que nascem são da linhagem da mãe. Se a criança for um menino, os filhos deste não Ihe seguirão a linhagem (ISAAC, 2004).

Os Bororo fazem o ritual do Boe Etore eie Paru 'batizado Bororo', durante o dia, as mulheres do sub clã paterno confeccionarão enfeites como Jipa Kejewu, 'enfeite Bororo colocado na parte lateral da cabeça da criança acima da orelha na nominação', e o Kudu Kejewu, 'enfeite Bororo colocado na parte frontal da cabeça da criança na nominação', e o Kiogwaro pelos homens do sub clã paterno, e, à noite, se canta. No outro dia, se faz a nominação da criança, e é interessante ressaltar que o padrinho será um dos parentes da mãe da criança, e os nomes são específicos do sub clã da mãe (SOUZA, 2014).

De acordo com Ochoa Camargo (2010), quando a criança do sexo masculino passa a ser considerada uma pessoa adulta na comunidade, passa por um ritual de iniciação que se chama Iparedo ó badodu, 'iniciação dos rapazes'. Esse ritual ocorre nos três últimos dias de um funeral, ou de forma isolada, e denomina-se: Aroe Emagurudodu, 'descanso das almas'.

Ainda segundo o autor supracitado, os Bororo também praticam o ritual, todavia com respeito, não fazem as coisas Paga paga (de qualquer jeito), como 
os próprios Bororo dizem. O esporte aqui elencado é a corrida com duas rodas de caeté, esse ritual sagrado para os Bororo se chama Mano, cortam em talos e fazem duas grandes rodas, unindo os talos. Os dois grandes clãs fazem as rodas para o outro, os Ecerae fazem a grande roda para os Tugarege e os Tugarege, para os Ecerae. O mano é retirado de uma lagoa e se canta a noite inteira para que, no outro dia, aconteça a corrida, o ritual se chama Mano Paru, 'corrida do mano'.

Nesse ritual, as mulheres competem entre os dois grandes clãs e correm levando os talos do mano até o lugar que os Bororo denominam de Mano Pa, que quer dizer lugar do mano. Quando é a vez dos homens correrem com o mano do Mano Pa até o Bororo (pátio da aldeia), depois que a grande roda está pronta, as mulheres se escondem porque os homens correm com as almas, e este ritual é restrito aos homens, nem mesmo os rapazes que ainda não foram iniciados podem participar. É uma competição entre os dois grandes clãs (OCHOA CAMARGO, 2010).

Os Bororo ainda têm o ritual do Kare Eparu, 'pescaria Bororo', feito não somente em funerais, os Bororo se juntam para pescar, e também se tem a presença dos Aroe. Da mesma forma que ocorre o Kare Paru, acontece com o Barege Paru 'caçada Bororo' (SOUZA, 2014).

Os Bororo se ajuntam e fazem o Boe Maguru, 'acampamento para caçar e pescar', que dura dias e até semanas na beira de rio e matas. São os mesmos procedimentos do Kuro Paru, 'pesca com timbó'; com o Boe Paru, porém, na maioria das vezes e dependendo de onde se situa o ambiente geográfico dos Bororo, se faz numa lagoa que os Bororo chamam Kurugwa. Utiliza-se um tingui (tipo de cipó), de nome Bororo Kuro, que libera líquidos que retiram o oxigênio da água por um tempo, fazendo com que os peixes comecem a morrer. Depois de um tempo, a água volta ao seu estado normal de oxigenação. Outros tipos de vegetais utilizados pelos Bororo são Kudo i biri, a casca da árvore timbó e de tamburi Pae Ewiareu i biri.

O Ritual do casamento Bororo é composto por dois quesitos: 1) O casamento era predeterminado pela família na escolha do esposo para filha e seguia os seguintes critérios: o rapaz pretendido devia ter boa conduta dentro da sociedade Bororo, dominar as técnicas de caça e pesca e fabricação de adornos, entre outros; 2) namoro em segredo: Após a descoberta pelos pais da mulher, realizava-se o casamento. Essa cerimônia já não é vista rotineiramente (OCHOA CAMARGO, 2010). 
O Oieigo ${ }^{13}$ é um ritual privativo aos sub clãs dos Iwagudo, Ki Bakororo (clã dos Kiedo) e Aroia Kurireu (clã dos /wagudodoge). O Consultor Nativo ${ }^{14}$ disse que, antigamente, esse ritual era somente para esses dois sub clãs Bororo. Faz-se esse ritual quando não tem o funeral, em casos de pessoas que quase faleceram e voltaram à vida e, também, quando um Bororo já sabe que vai falecer (SOUZA, 2014).

Os animais são importantes para os rituais, para a cultura e para a organização social do povo. Segundo a tradição Bororo, os animais foram criados conforme o mito que descreve a subida dos jovens Bororo ao céu. Esse mito conta que as muIheres iam, todos os dias, à roça e não traziam nada aos filhos, diziam que o milho ainda não estava em ponto de coleta. Ao descobrirem que as mulheres estavam mentindo, os meninos decidiram ir embora, fizeram um piodudo (beija-flor) levar um cipó até o céu e começaram a subir um por vez. As mulheres descobriram e subiram atrás de seus filhos, pois acreditam que as crianças se tornaram animais.

De acordo com Albisetti e Venturelli (1962), o Bororo que viu primeiro certos seres ou fez por primeiro certos objetos, reservou, acerca deles e para os membros do próprio clã, direitos de primazia e de propriedade, mas não de uso exclusivo. Assim, por exemplo, o Bororo que viu o Kuje (mutum), disse que, pelo fato de o animal estar em sua presença, este seria de sua propriedade. Tal primazia não traz, porém, nenhum direito ao proprietário, em se tratando de animais, de modo que qualquer um desses seres pode ser morto e comido, sem restrição ou lesão de direitos alheios.

No caso de objetos que sirvam de enfeites, como por exemplo, as penas de Kurugugwa (gavião caracarai), somente os membros do clã possuidor podem usá-lo. Muitos objetos privativos dos clãs não são usados, em geral, apenas pelos membros destes, mas também por outros que se tornaram dignos de recebê-los de presente por alguma ação especial, como por exemplo, pela matança de uma onça.

Quem recebe o presente tem direito de usá-lo como se fosse de seu sub clã ou clã. Aí está fundamentada a justificativa das divisões dos mamíferos, aves e peixes de acordo com a primazia de cada sub clã, porque, para os Bororo, quem viu primeiro algum objeto tem direito sobre ele.

\footnotetext{
${ }^{13}$ Retomada de vida do Bororo que passou por alguma superação durante a vida.

${ }^{14}$ Joaquim Toroa, residente na Terra Indígena de Tadarimana, no município de Rondonópolis, MT, foi o consultor nativo, no ano de 2014.
} 


\section{PROCEDIMENTOS METODOLÓGICOS}

Utilizando os fundamentos de Angrosino (2009) e Minayo (2008), esta pesquisa tem caráter etnográfico, sendo fundamentalmente qualitativa. Por ter um caráter descritivo e exploratório, esse estudo etnográfico visou registrar aspectos da cultura Bororo, mais especificamente, a relação desse povo com os animais em suas práticas culturais e organização social.

Segundo Angrosino (2009), a etnografia permite compreender as formas costumeiras de viver de um determinado grupo social. Para Minayo (2008), a opção pela abordagem qualitativa se deve ao fato de que os aspectos da realidade investigada não podem ou não deveriam ser quantificados, o que é bastante comum em pesquisas sociais que apresentam questões muito particulares.

A pesquisa ocorreu durante os anos de 2014 e 2015. O locus de investigação foi a comunidade da TI de Tadarimana, localizada no município de Rondonópolis ${ }^{15}$ situada ao sul do estado de Mato Grosso, a 45 quilômetros do centro da cidade.

$\mathrm{O}$ estudo foi realizado em duas etapas, inicialmente, junto à comunidade indígena, que é o principal alvo a ser investigado e, posteriormente, por meio de pesquisas teóricas, utilizando como fontes os livros, artigos, documentos, publicações, entre outras existentes sobre o assunto. Esse tipo de procedimento, no qual se buscam, inicialmente, os saberes locais e, posteriormente, o embasamento teórico, é indicado por Angrosino (2009) para estudos do tipo etnográfico.

Os dados dessa pesquisa foram obtidos por meio da observação participante e a utilização de entrevistas semiestruturadas e abertas, realizadas com o consultor nativo. De acordo com Gil (2010), a pesquisa participante possibilita a recriação de dentro para fora e vai oportunizar a expressão das formas concretas de um grupo, as manifestações próprias das pessoas.

Uma vez que pesquisar é participar, durante todo o período de coleta de dados, o fato de o pesquisador ser pertencente a essa etnia, favoreceu a interlocução com a comunidade e, principalmente, com o consultor nativo. As entrevistas foram feitas com o conhecedor da cultura Bororo, o ancião de nossa comunidade, o Consultor Nativo Joaquim Toroa, Bororo e morador da Aldeia Tadarimana (Figura 3).

${ }^{15}$ Cidade que fica ao sul do Estado de Mato Grosso. 
Figura 3 - Consultor nativo Joaquim Toroa

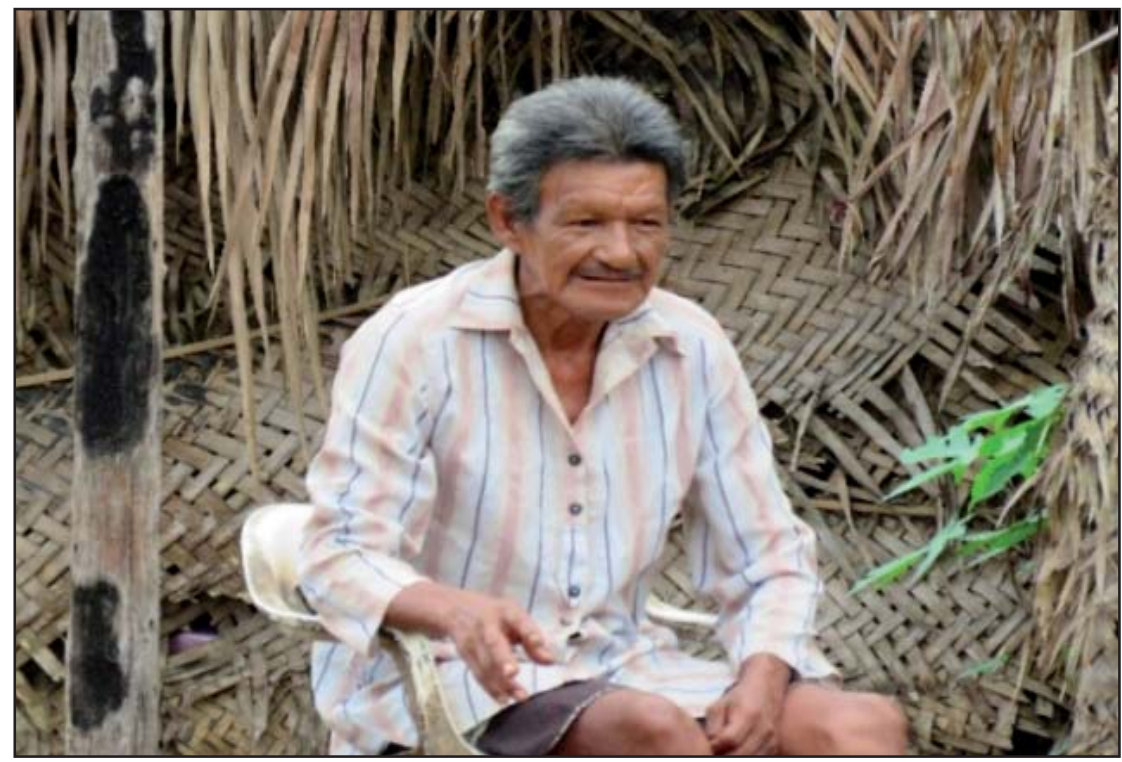

Foto: Arquivo pessoal (2015).

Esse participante é esposo da tia do pesquisador, portanto, pertencentes ao mesmo Clã. Cabe aqui registrar que a confiança já estabelecida entre os interlocutores trouxe aos momentos de entrevista uma certa tranquilidade, em que as interações transcorriam sem restrições ou formalidades.

O consultor Joaquim Toroa é um Bororo bastante disponível em ensinar aos mais jovens, trabalhou na Escola Municipal Indígena Leosídio Fermau, como monitor do Programa Mais Educação no Macro campo "Artesanatos Regionais", quando ensinava aos alunos Bororo a confecção do Akigu Bororo (tecido feito de linha de algodão para colocar nos pulsos, cabeças e nos braços).

Além de concordar em participar voluntariamente deste estudo, o ancião se mostrou muito interessado e até preocupado, ao proferir estas palavras: "A cultura tem que ser escrita no papel para os mais jovens aprender, por exemplo, meu Oieigo (canto tradicional) está tudo no bapera (papel), quando eu esqueço eu olho de novo para lembrar o canto!" (Joaquim Toroa). O entrevistado disse ainda que, apesar de o mundo estar sofrendo muitas mudanças, ainda dá para os jovens Bororo se interessarem pela cultura de seu povo. 
As conversas e entrevistas, realizadas em língua materna, criaram a oportunidade de que o ancião se manifestasse, por meio de suas narrativas, sobre temas como meio ambiente (animais), cultura e o futuro da comunidade (principalmente, em relação aos mais jovens). Todos os momentos de entrevistas foram gravados via aparelho telefônico móvel, da marca Samsung, para, posteriormente, serem transcritas.

Os dados coletados foram organizados por assunto, partindo da relação dos Bororo com a natureza, priorizando as relações desse povo com os animais nos aspectos culturais e na forma de organização social. A interpretação desses dados ocorreu no âmbito da descrição, o que é indicado por Angrosino (2009) para a realização de pesquisas etnográficas e observacionais.

\section{RESULTADOS E DISCUSSÕES}

\subsection{A relação dos Bororo com a natureza}

Antigamente, os Bororo eram coletores de frutas silvestres, andavam por lugares onde havia frutas em cada época; quando acabavam essas frutas, deslocavam-se de um lugar para outro em busca de novos alimentos. Devido a esse costume, os Bororo, de forma geral, como os outros povos indígenas, eram conhecidos como preguiçosos, pois não tinham costume de realizar trabalhos braçais como plantar (Joaquim Toroa).

Nas comunidades Bororo atuais, se veem plantações de subsistência para o consumo próprio de cada família, não produzem em grande escala e não praticam a monocultura. As principais práticas de agricultura dos Bororo são o plantio de mandioca, milho e abóbora. Vivem da caça e da pesca como subsistência, nas suas matas são encontrados muitos Jugo 'queixada', Jui 'caititu', Okwaru 'tatu peba', Kudobo 'quati', que são caças apreciadas pelos Bororo. Nos seus rios são encontrados o Orari 'pintado', Roko 'corimba', Araru 'piraputanga', Pobu 'espécie de pacu', Okoge 'dourado' e vários outros peixes que também são apreciados pelos Bororo (Joaquim Toroa).

Os recursos financeiros, hoje, na aldeia, estão baseados nos salários dos funcionários das escolas municipal e estadual, como professores, Asd's, funcionários da saúde como Ais (Agente de saúde), técnico de enfermagem, Aisan (Agente de 
saneamento), motorista da saúde. Temos os aposentados, pensionistas, Programas Sociais (Bolsa Família), vendas de produtos alimentícios, tais como: refrigerantes, pães, salgados, peixes de tanques, bolachas, frango de granja e outros.

São um povo pacífico que vive em terras demarcadas, porém, se encontram em disputa de terras, não com os não índios, mas com indígenas da etnia xavante na TI Merure. Na região do Sangradouro, recentemente, ocorreram conflitos entre os Bororo e Xavante, e os Bororo se viram obrigados a deixar suas terras pelo fato de serem minoria no local. Na região de Jarudori também tem o conflito de terra entre os indígenas e os brancos (Joaquim Toroa).

Dentro da TI, já tem instalada uma vila que se chama Jarudori, e o problema ainda se arrasta na justiça. Os Bororo da aldeia de Tadarimana são bastante acolhedores, porém, essa qualidade tem que ser vista com cautela pois, recentemente, há uma entrada desenfreada de não índios na TI Tadarimana, devido aos muitos casamentos com homens bororo. Talvez essa miscigenação venha a ocasionar uma descaracterização do Povo como indígena. Conforme a orientação do Boe Akaru, nas relações das metades exogâmicas, Tugoarege e Ecerae, não era para nenhum homem ou mulher bororo ter relações conjugais com pessoas que não são do povo Bororo, cada clã tem sua estrada social, onde vai formar família em outra metade exogâmica (Joaquim Toroa).

O Povo Bororo, pela sua cultura, não tem o hábito de acumular patrimônios como bens materiais, todavia a integração desse povo na sociedade como cidadãos força-os a serem inseridos dentro do sistema do não índio. Um exemplo claro é de, atualmente, se dar mais importância aos estudos.

Antigamente, a escola era privilégio de poucos; hoje, como faz parte das políticas públicas, cabendo ao Governo cumprir e executar ações no sentido de implantar escolas, isso dá abertura para novos sonhos entre os membros da comunidade indígena, de realmente se tornarem algo na sociedade, exercendo uma profissão dentro de sua comunidade, como professor, enfermeiro, advogado, entre outras funções. Mas o fato é de que os indígenas estão buscando espaços dentro da sociedade em que vivem, e isso é visto como algo muito positivo. 


\subsection{Relação dos animais com os grupos sociais - Clãs}

Os Bororo possuem sua organização social relacionada com a divisão dos animais. Cada sub clã tem animais com as suas propriedades, que receberam nomes específicos, sendo que muitos deles não são conhecidos em língua portuguesa, mas somente na língua materna. Os nomes dos animais e a maneira de organização social com a atribuição de propriedades foram repassados de geração em geração, conhecimentos esses que são preservados pelos indígenas pertence ao sub clã Baadojebage (clã dos chefes), um importante grupo dentro da Comunidade Bororo.

Considerando as informações prestadas pelo consultor nativo, apresentaremos a seguir quadros demonstrativos das classificações de acordo com a propriedade de cada sub clã Bororo. As propriedades dos grupos sociais foram organizadas nesse estudo conforme a divisão da biologia nas seguintes classificações: Mamíferos, Anfíbio, Répteis, Aves e Peixes.

A intenção de apresentar esses dados não é a quantidade dos seres para cada sub clã e, sim, mostrar que esse povo teve um critério de divisão dos animais. As propriedades desses dois grandes Clãs Bororo seguem apresentadas separadamente, ou seja, as propriedades da metade dos Ecerae (Quadro 1), contendo os seus sub clãs: Baadojeba, Kie, Bokodori Ecerae e Bakoro Ecerae e as propriedades da outra metade exogâmica dos Tugarege (Quadro 2), no qual apresentamos os seguintes sub clãs: Paiwoe, Apiborege, Iwagudo e Aroroe.

Quadro 1 - Divisão das propriedades por sub clã da metade exogâmica Ecerae

\begin{tabular}{|c|c|c|c|}
\hline \multicolumn{4}{|c|}{ Mamíferos } \\
\hline Baadojeba & Kie & Bokodori Ecerae & Bakoro Ecerae \\
\hline $\begin{array}{l}\text { Bakurere (parecido } \\
\text { com macaco); Bokodori } \\
\text { kujagureu (tatu } \\
\text { canastra); } \\
\text { Rea (tatu galinha). }\end{array}$ & $\begin{array}{l}\text { Aigo (onça parda); } \\
\text { Aipobureu } \\
\text { (jaguatirica); } \\
\text { Amo (semelhante à } \\
\text { lebre); } \\
\text { Apu (paca); } \\
\text { Bacieje (veado } \\
\text { campeiro macho); } \\
\text { Bokodori Coreu (tatu } \\
\text { canastra preto); } \\
\text { Ki (anta); } \\
\text { Pobogo (veado } \\
\text { mateiro). }\end{array}$ & $\begin{array}{l}\text { Akuarea (gato); } \\
\text { Arigao Kigadureu (cão } \\
\text { branco }{ }^{16} \text { ); } \\
\text { Barogo kurireu (cavalo); } \\
\text { Bokodori (tatu gigante); } \\
\text { Bokodorireu (tipo de tatu); } \\
\text { Cabrito; } \\
\text { Carneiro; } \\
\text { Iturawori (tatu da floresta); } \\
\text { Jugureu (porco doméstico); } \\
\text { Kodo kodo (serelepe); } \\
\text { Tapira (vaca); } \\
\text { Tu (burro). }\end{array}$ & $\begin{array}{l}\text { Adugo Coreu (onça } \\
\text { preta); } \\
\text { Adugo (onça } \\
\text { pintada); } \\
\text { Jerego (tatu liso); } \\
\text { Okwaru (tatu } \\
\text { peba). }\end{array}$ \\
\hline
\end{tabular}

${ }^{16}$ Se o cachorro for da cor branca, pertence a esse determinado sub clã; se tiver outra cor, já pertencerá a outro sub clã. 


\begin{tabular}{|c|c|c|c|}
\hline \multicolumn{4}{|c|}{ Anfíbios } \\
\hline Baadojeba & Kie & Bokodori Ecerae & Bakoro Ecerae \\
\hline $\begin{array}{l}\text { Não existe anfíbios para } \\
\text { este sub clã. }\end{array}$ & $\begin{array}{l}\text { Não existe anfíbios } \\
\text { para este sub clã. }\end{array}$ & $\begin{array}{l}\text { Não existe anfíbios para } \\
\text { este sub clã. }\end{array}$ & $\begin{array}{l}\text { Não existe anfíbios } \\
\text { para este sub clã. }\end{array}$ \\
\hline \multicolumn{4}{|c|}{ Répteis } \\
\hline Baadojeba & Kie & Bokodori Ecerae & Bakoro Ecerae \\
\hline $\begin{array}{l}\text { Uwai Kigadureu (jacaré } \\
\text { branco }{ }^{17} \text { ). }\end{array}$ & Upe (tartaruga). & $\begin{array}{l}\text { Não existe répteis para este } \\
\text { sub clã. }\end{array}$ & Ice (jiboia). \\
\hline \multicolumn{4}{|c|}{ Aves } \\
\hline Baadojeba & Kie & Bokodori Ecerae ${ }^{18}$ & Bakoro Ecerae \\
\hline $\begin{array}{l}\text { Bace Koguio (tuiuiú); } \\
\text { Baruare (ave dos } \\
\text { campos); } \\
\text { Barugi (pequeno gavião); } \\
\text { Ciwabo (japuíra); Enari } \\
\text { (pica pau da cabeça } \\
\text { vermelha); } \\
\text { Eregejeje (espécie de } \\
\text { pica pau); } \\
\text { Kadamo (espécie de } \\
\text { Martim pescador); } \\
\text { Kadomo (Martim } \\
\text { pescador); } \\
\text { Mace Jeparu Kujagureu } \\
\text { (tipo de cabeça seca); } \\
\text { Meri (tié fogo); } \\
\text { Ó Kujagureu (socó } \\
\text { vermelho19); } \\
\text { Parigogo (jacu); } \\
\text { Tui-Tui (canário da terra). }\end{array}$ & $\begin{array}{l}\text { Apodo Oto Coreu } \\
\text { (tucano do bico } \\
\text { preto); } \\
\text { Apodo (espécie de } \\
\text { tucano); } \\
\text { Bai (urubu); } \\
\text { Bataro Coreu (João } \\
\text { pinto); } \\
\text { Bika (anu branco); } \\
\text { Boroibe (pavãozinho } \\
\text { do Pará); } \\
\text { Ciwabo (Japuíra); } \\
\text { Ciwotorogo (espécie } \\
\text { de pássaro); } \\
\text { Kudoro (araraúna); } \\
\text { Kuo (jaó); } \\
\text { Ori (anu preto); } \\
\text { Pari (ema); } \\
\text { Porowe (japuíra). }\end{array}$ & $\begin{array}{l}\text { Aogwa (tico-tico-rei); } \\
\text { Baruare (pequeno pássaro } \\
\text { preto); } \\
\text { Bataro kujagureu (João } \\
\text { pinto vermelho); } \\
\text { Cenatatao (gralha-cancã); } \\
\text { Cibae (araracanga); } \\
\text { Ciwabo (japuíra); } \\
\text { Kadagare (variedade de } \\
\text { Martim pescador); } \\
\text { Kagariga (galinha); } \\
\text { Kuo Kurireu (galinha da } \\
\text { angola); } \\
\text { Meriaku (pássaro pequeno } \\
\text { tié fogo); } \\
\text { Piru (peru); } \\
\text { Pogo (anu branco); } \\
\text { Turubare Kigadureu (pato } \\
\text { branco); } \\
\text { Turubare (ganso/marreco). }\end{array}$ & $\begin{array}{l}\text { Aribo Ekureu } \\
\text { (passarinho apara } \\
\text { pedra); } \\
\text { Ciwabo (japuíra); } \\
\text { Ó Coreu (socó } \\
\text { preto); }\end{array}$ \\
\hline \multicolumn{4}{|c|}{ Peixes } \\
\hline Baadojeba & Kie & Bokodori Ecerae & Bakoro Ecerae \\
\hline $\begin{array}{l}\text { Okoge Bakororo (grande } \\
\text { dourado); } \\
\text { Okoge Kujagureu } \\
\text { (dourado vermelho); } \\
\text { Pobu (espécie de pacu); } \\
\text { Reko (traíra). }\end{array}$ & $\begin{array}{l}\text { Okoge Coreu } \\
\text { (dourado preto); } \\
\text { Okoge Kaworu } \\
\text { (dourado verde). }\end{array}$ & $\begin{array}{l}\text { Okoge (variedade de } \\
\text { dourado); } \\
\text { Motoreu (sardinha). }\end{array}$ & $\begin{array}{l}\text { Bokwari (peixe); } \\
\text { Buiogo (piranha); } \\
\text { Je Kujagureu (piava } \\
\text { vermelha); } \\
\text { Okoge Jerigi Are (va- } \\
\text { riedade de dourado); } \\
\text { Okoge Paiwareu } \\
\text { (tipo de dourado). }\end{array}$ \\
\hline
\end{tabular}

Fonte: Dados coletados na pesquisa (2015).

17 O jacaré branco pertence ao Sub Clã dos Baadojebage (os Bororo têm os detalhes de cores dos animais).

${ }^{18}$ Segundo o Consultor nativo, todas as aves que são domesticadas são pertencentes ao Sub Clã dos Bokodori Ecerae.

${ }^{19}$ O socó vermelho pertence ao Sub Clã dos Baadojebage, e o da cor preta pertence aos Bakoro Ecerae. 
Nota-se que os Bororo tiveram poucas propriedades nos anfíbios, talvez porque isso não fosse interessante a eles. Os motivos que levam a essa pouca atenção aos anfíbios e répteis é uma sugestão de investigação futura.

Quadro 2 - Divisão das propriedades por sub clã da metade exogâmica Tugarege

\begin{tabular}{|c|c|c|c|}
\hline \multicolumn{4}{|c|}{ Mamíferos } \\
\hline Paiwoe & Apiborege & Iwagudo & Aroroe \\
\hline $\begin{array}{l}\text { Amo (coelho); } \\
\text { Apogo (tamanduá } \\
\text { mirim); } \\
\text { Atubo (veado } \\
\text { galheiro); } \\
\text { Buke (tamanduá- } \\
\text { bandeira); } \\
\text { Iwe (ouriço); } \\
\text { Juko (tipo de macaco); } \\
\text { Mea (cutia); Pai } \\
\text { (bugio). }\end{array}$ & $\begin{array}{l}\text { Awogodori (tipo de } \\
\text { jaguatirica grande); } \\
\text { Bakure (macaco } \\
\text { noturno); }\end{array}$ & $\begin{array}{l}\text { Akiwa (capivara); } \\
\text { Arigao (cão, sem ser } \\
\text { da cor branca); } \\
\text { Kiwareu (rato); } \\
\text { Kurugo (preá). }\end{array}$ & $\begin{array}{l}\text { Bokwari (grande lontra); } \\
\text { Ierarai (guaxinim); } \\
\text { Ipie (ariranha); } \\
\text { Ipocereu (irara); } \\
\text { Jomo (tipo de lontra); } \\
\text { Jugo (queixada); } \\
\text { Jui (caititu); } \\
\text { Kudobo (quati); } \\
\text { Kudugi (variedade de } \\
\text { macaco); } \\
\text { Meridabo (furão); } \\
\text { Moribo (cão silvestre); } \\
\text { Okwa (lobinho); } \\
\text { Ratugero (outro } \\
\text { lobinho); } \\
\text { Tarigo (javali). }\end{array}$ \\
\hline \multicolumn{4}{|c|}{ Anfíbios } \\
\hline Paiwoe & Apiborege & Iwagudo & Aroroe \\
\hline$R u$ (sapo). & $\begin{array}{l}\text { Não existe anfíbios } \\
\text { para este sub clã. }\end{array}$ & $\begin{array}{l}\text { Não existe anfíbios } \\
\text { para este sub clã. }\end{array}$ & $\begin{array}{l}\text { Não existe anfíbios para } \\
\text { este sub clã. }\end{array}$ \\
\hline \multicolumn{4}{|c|}{ Répteis } \\
\hline Paiwoe & Apiborege & Iwagudo & Aroroe \\
\hline $\begin{array}{l}\text { Ato (jabuti); } \\
\text { Jerigigi (pequeno } \\
\text { cágado); } \\
\text { Uwai Coreu (jacaré } \\
\text { preto). }\end{array}$ & $\begin{array}{l}\text { Atomoio (tartaruga de } \\
\text { rio); } \\
\text { Irui (camaleão). }\end{array}$ & Não identificado. & Bakororeu (cobra coral). \\
\hline \multicolumn{4}{|c|}{ Aves } \\
\hline Paiwoe & Apiborege & Iwagudo & Aroroe \\
\hline $\begin{array}{l}\text { Bace Akorogoreu (tipo } \\
\text { de Garça); } \\
\text { Bi (coruja); } \\
\text { Ciwabo (japuíra ou } \\
\text { guacho); } \\
\text { Curui (papagaio- } \\
\text { urubu); Keakorogu } \\
\text { (periquito estrela); }\end{array}$ & $\begin{array}{l}\text { Aroe Eceba (gavião- } \\
\text { real); } \\
\text { Bace Kuguio (tuiuiú); } \\
\text { Bace (garça); } \\
\text { Baire eke apedo (João } \\
\text { de barro); } \\
\text { Beo seriema); } \\
\text { Cugui (araçaripoca); }\end{array}$ & $\begin{array}{l}\text { Aere (urutau); } \\
\text { Aroe Bai (grande } \\
\text { gavião); } \\
\text { Bakuja (urubu); } \\
\text { Ceje (tipo de gavião- } \\
\text { fumaça preto); } \\
\text { Ciwaje (urubu- } \\
\text { caçador); }\end{array}$ & $\begin{array}{l}\text { Bakuguma (gavião- } \\
\text { requinta); } \\
\text { Batagaje (biguá); } \\
\text { Korao (papagaio } \\
\text { verdadeiro); } \\
\text { Mano (variedade de } \\
\text { gavião); } \\
\text { Metugo (pomba silvestre); }\end{array}$ \\
\hline
\end{tabular}




\begin{tabular}{|c|c|c|c|}
\hline \multicolumn{4}{|c|}{ Aves } \\
\hline Paiwoe & Apiborege & Iwagudo & Aroroe \\
\hline $\begin{array}{l}\text { Kerekere (variedade de } \\
\text { ararinha); } \\
\text { Kugo (gavião- } \\
\text { quiriquiri); } \\
\text { Kugu (variedade de } \\
\text { coruja); } \\
\text { Kuido (arara amarela); } \\
\text { Kuno (papagaio } \\
\text { araçá ou papagaio- } \\
\text { campeiro); } \\
\text { Kuritaga (papagaio- } \\
\text { corneteiro); } \\
\text { Makao (macauã); } \\
\text { Mokuruwodo } \\
\text { (corujão); Ore } \\
\text { (ararinha); } \\
\text { Piabo (surucuá); } \\
\text { Tagogo (corujinha); } \\
\text { Tano (quero-quero); } \\
\text { Turubare Coreu } \\
\text { (variedade de pato } \\
\text { preto). }\end{array}$ & $\begin{array}{l}\text { Kugarure (butuíra da } \\
\text { praia); } \\
\text { Kurugugwa porireu } \\
\text { (outros tipos de } \\
\text { gaviões); } \\
\text { Kurugugwa (gavião- } \\
\text { caracaraí); } \\
\text { Parabara (marreco); } \\
\text { Raporepore (passari- } \\
\text { nho mexeriqueiro); } \\
\text { Tawie Kigadureu } \\
\text { (taiamã); } \\
\text { Tawie (gaivota do } \\
\text { pantanal); } \\
\text { Toroa (espécie de } \\
\text { gavião); } \\
\text { Tudu (coruja } \\
\text { caburezinho). }\end{array}$ & $\begin{array}{l}\text { Iwagudu Keao Keao } \\
\text { (gralha); } \\
\text { Karao (tipo de ave } \\
\text { das lagoas); } \\
\text { Keagu (tipo de gavião } \\
\text { fumaça castanho); } \\
\text { Kido (periquito); } \\
\text { Kidoreu (sanhaço); } \\
\text { Kocaga (saracura); } \\
\text { Kuje (mutum); } \\
\text { Kujibo (tipo } \\
\text { de cardeal); } \\
\text { Maridogareu } \\
\text { (pássaro pequeno); } \\
\text { Mokureabo (urutau); } \\
\text { Piodudu (beija-flor); } \\
\text { Piroje (tipo de } \\
\text { andorinha); Pobureu } \\
\text { (urubu); Pogoriwo } \\
\text { (andorinha); Pogubo } \\
\text { (galo campina que } \\
\text { fica na beira do rio); } \\
\text { Uwarinogo (gavião } \\
\text { tesoura). }\end{array}$ & $\begin{array}{l}\text { Nabure (arara } \\
\text { vermelha); } \\
\text { Tamigi (anhuma). }\end{array}$ \\
\hline \multicolumn{4}{|c|}{ Peixes } \\
\hline Paiwoe & Apiborege & Iwagudo & Aroroe \\
\hline $\begin{array}{l}\text { Akoro (barbado); } \\
\text { Koma (jurupoca); } \\
\text { Kudogo (botoado); } \\
\text { Noareu (variedade de } \\
\text { bagre); } \\
\text { Orari (pintado); } \\
\text { Orarije (variedade de } \\
\text { surubim); } \\
\text { Poru (jaú); } \\
\text { Rekudo (surubim); } \\
\text { Rokoreu (tipo de } \\
\text { lambari). }\end{array}$ & $\begin{array}{l}\text { Apeareu (tipo de } \\
\text { lambari); } \\
\text { Apuie (lambari } \\
\text { itiquira); } \\
\text { Enokureu (tipo de } \\
\text { lambari); } \\
\text { Roko (corimba); Tubore } \\
\text { (lambari). }\end{array}$ & $\begin{array}{l}\text { Akurara (pacu peva); } \\
\text { Araru (piraputanga); } \\
\text { Buruwo (pequeno } \\
\text { peixe); } \\
\text { Jarudo (tipo de } \\
\text { bagre). }\end{array}$ & $\begin{array}{l}\text { Não existe peixes para } \\
\text { este sub clã. }\end{array}$ \\
\hline
\end{tabular}

Fonte: Dados coletados na pesquisa (2015).

Os quadros apresentados organizados nos moldes de classificação como mamíferos, anfíbios, répteis, aves e peixes deram a oportunidade de fazer uma comparação do Povo Bororo quanto à classificação zoológica nas ciências naturais 
dos não indígenas, cabe salientar que a classificação de propriedade desse povo não segue os moldes da ciência eurocêntrica.

Um aspecto relevante a ser considerado é que foram considerados como propriedade somente os animais vertebrados, o que pode estar atrelado ao conceito de animais que os indígenas dessa etnia possuem. Cabe lembrar que não foi mencionado nenhum representante dos artrópodes, que são o grupo de animais com maior quantidade de espécies conhecidas. No estudo realizado por Razera, Boccardo e Pereira (2006), com estudantes indígenas Tupinambá sobre suas concepções da fauna, o grupo dos animais vertebrados foi o mais lembrado, contabilizando $87,2 \%$ dos animais listados como fauna brasileira.

Pelos dados contidos nos Quadros 1 e 2, pode-se perceber também que os sub clãs possuem um grande número de animais de diferentes classes, principalmente das aves e dos mamíferos. Por outro lado, a classe dos anfíbios não tem nenhum ou apenas um representante nos sub clãs Bororo, talvez essa classe não seja tão importante a esse povo.

Merece destaque a expressiva quantidade de aves, o que demonstra a relação importante que elas exercem na cultura e organização social desse povo tradicional. Cabe ressaltar que as plumagens das aves são muito utilizadas nos enfeites dos Bororo. Comparando com os resultados dos Tupinambá, investigados por Razera, Boccardo e Pereira (2006), é possível perceber uma diferença, pois esses indígenas da Bahia indicaram possuir uma relação mais próxima com os mamíferos, mais do que com aves ou peixes.

A demonstração numérica proposta no Quadro 3 não tem o objetivo de mostrar quem tem maior ou menor propriedade, porém, de incrementar a reflexão sobre o modo próprio aos Bororo de apropriar-se e dividir os animais entre si. 
Quadro 3 - Total de propriedades dos sub clãs por classificação de animais

\begin{tabular}{|l|c|c|c|c|c|c|}
\hline \multicolumn{1}{|c|}{ Sub Clã } & Mamíferos & Anfíbios & Répteis & Aves & Peixes & Total \\
\hline Baadojeba & 3 & 0 & 1 & 13 & 4 & 21 \\
\hline Kie & 8 & 0 & 1 & 13 & 2 & 24 \\
\hline Bokodori Ecerae & 12 & 0 & 0 & 14 & 2 & 28 \\
\hline Bakoro Ecerae & 4 & 0 & 1 & 3 & 5 & 13 \\
\hline Paiwoe & 8 & 1 & 3 & 18 & 9 & 39 \\
\hline Apiborege & 2 & 0 & 2 & 15 & 5 & 24 \\
\hline Iwagudo & 4 & 0 & 0 & 21 & 4 & 29 \\
\hline Aroroe & 14 & 0 & 1 & 7 & 0 & 22 \\
\hline
\end{tabular}

Fonte: Dados coletados na pesquisa (2015).

Conforme pode ser notado no Quadro 3, no Clã Ecerae, o sub clã dos Bokodori Ecerae é o que possui mais propriedades de mamíferos, e o sub clã dos Baadojebage tem menos. Já no Clã Tugarege, o sub clã dos Aroroe é o que apresenta maior quantidade de representantes, seguidos de Paiwoe, Iwagudo e Apiborege.

Um dado interessante que consta no quadro é o fato de que nenhum sub clã da metade dos Ecerae tem alguma propriedade nos anfíbios e na outra metade (Tugarege), somente o sub clã Paiwoe possui uma única propriedade. Outro dado constatado demonstra que os Bororo têm pouca propriedade nos seus sub clãs no que se refere a répteis, sendo um pouco maior a quantidade nos sub clãs da metade Tugarege.

Outro dado que chama a atenção é o fato de serem aves as maiores quantidades de propriedades. Tanto na metade dos Ecerae como dos Tugarege, destacam-se três sub clãs em cada e um deles com poucas propriedades, que é o caso do sub clã dos Bakoro Ecerae e do sub clã Aroroe, respectivamente um de cada metade. Em relação aos peixes, as propriedades dos sub clãs se mantêm com uma quantidade relativamente baixa quando comparado com as aves e com os mamíferos. Além disso, o sub clã Aroroe sequer possui peixes como representantes.

Ainda pode ser notado, no Quadro 3, que, na metade dos Ecerae, o Sub Clã dos Bokodori Ecerae tem maior número de representantes (28), logo em seguida vem o sub clã dos Kiedo (24), posteriormente o sub clã dos Baadojeba (21) e Bakoro Ecerae (13). Na metade dos Tugarege. o sub clã doa Paiwoe tem 
maior número de representantes (39), seguido dos /wagudo (29), posteriormente Apiborege (24) e Aroroe (22).

Os quadros demonstrativos, organizados de acordo com a classificação da Ciência dos nãos indígenas, demonstram que os Bororo, envolvendo os dois grandes Clãs (Ecerae e Tugarege), obtiveram mais para si como propriedade, com primazia os mamíferos, aves e peixes, esses tendo grande representação de propriedade dos sub clãs. Por outro lado, as classes dos répteis e anfíbios possuem pouca representação numérica.

O que nos abre outro leque é que, com essa divisão feita pelos Bororo, será possível um norteamento aos materiais utilizados nos enfeites, aos nomes Bororo e outros aspectos. Tudo segue essa divisão, como por exemplo, em relação a um enfeite do sub clã dos Baadojeba que se chama Kiogo aro (Enfeite com penas), o que vai diferenciar esse enfeite de outros sub clãs é a presença da pena de Barugi (Gavião), pois essa ave é propriedade dos Baadojebage. Esse ordenamento segue também nos nomes pessoais dos Bororo, que não são somente de mamíferos, aves e peixes, e, sim, incluem os nomes de outros seres da natureza com os quais os Bororo também mantêm uma relação de propriedade.

\subsection{Rituais tradicionais: caçada, pescaria e oferenda}

A relação com os animais é feita de forma tão harmoniosa que, na caçada dos Bororo, se entoa o roia de caçada com as almas e, quando os Bororo voltam da caçada com suas caças que são entregues para as Aroe Etujemage 'Mães das Almas', para posteriormente serem mandadas para a casa central, exige-se que o corte dos pedaços da caça seja feito de forma criteriosa. Estas são as partes que são mandadas para as almas se alimentarem na casa central: Icoro 'paleta', itowuia 'antebraço', kubaru 'parte da barriga', utaena 'pedaço do espinhaço da parte traseira do animal', bupona 'coxa', utori 'batata da perna', barogo bia 'orelha do animal'.

Os Bororo, da mesma forma que têm com os mamíferos, também têm uma relação de culto e embelezamento de suas práticas culturais relacionadas às aves. Alguns mamíferos servem para o ritual da oferenda ou vingança de um finado conhecido como Barege Boemoriae: Adugo 'onça pintada', Adugo Coreu 'onça preta', Aigo 'onça parda', Aipobureu 'jaguatirica', Ipocereu 'irara ou papa mel', Okwa 
'Iobinho', Rie 'lobo guará', Moribo 'cachorro do mato', leragadu 'raposa das mãos listradas', Aimeareu 'gato morisco', lerarai 'mão pelada - guaxinim'.

É importante lembrar que algumas aves servem de alimento aos Bororo, e outras não. Algumas aves servem também de Boe Moriae, que é a oferenda para um finado. As aves embelezam os enfeites desse povo na sua arte plumária. Além dos mamíferos, há algumas aves que também são para o ritual da oferenda ou vingança de um finado, denominadas Kiege Boemoriae: Aroe Eceba 'gavião real', Kurugugwa 'gavião caracarai', Makao 'acauã', Kugu 'tipo de coruja', Tagogo 'coruja do campo', Bi 'corujinha'.

No funeral, são utilizadas a plumagem de araras para enfeitar os restos mortais do finado, principalmente, o crânio, o que é confirmado por Souza (2014). Na nominação da criança Bororo são utilizadas as penugens de pato e também as penas de arara para fazer o Kudu Kejewue o Jipa Kejewu, para enfeitar a criança na cerimônia de nominação. No adorno da criança, que se chama Kiogoaru, também são utilizadas as penas de aves como a arara, papagaio, gavião e o guacho. Na saia das crianças, que é feita do Akigu, também são utilizadas penas de aves, principalmente, de arara.

Ao invocar as almas para dar sorte na pescaria, segundo o consultor nativo, não pode faltar cigarro, café, chimarrão. A pescaria com as almas acontece no funeral e pode acontecer também sem ser durante o funeral. O Aroe Enogwage serve para alimentar as pessoas que já partiram desta vida, então, é sempre importante fazer uma manifestação cultural de pescaria ou caça ou dança. O canto do kare paru chama os peixes para dar sorte.

Os peixes que os Bororo pescam nas pescarias com as almas são entregues para as Aroe Etujemage 'Mãe das Almas', que mais tarde os enviam para a Casa Central para refeição das almas. Esses pescados são cortados nas casas das pessoas que as preparam, porém isso é feito de forma criteriosa e tem todo um processo de corte dos retalhos. Os peixes pequenos serão cortados em três pedaços. Peixe grande é diferente: corta-se a cabeça e pedaços do espinhaço. Os pedaços dos peixes são: Kodora bokora (pedaço do pescoço), karo ra (espinhaço). O pedaço do rabo fica com quem carregou o peixe. 


\subsection{Kiogoaro Bororo}

Segundo o consultor nativo, as plumas das aves estão sempre presentes na cultura do Povo Bororo, são essas plumas que embelezam seus adornos e se constituem como características originais desse povo e de sua prática sociocultural. Pelo fato de haver toda uma primazia de cada sub clã em relação às aves, essa primazia se repete nos adornos originais de cada sub clã, como veremos a seguir, no que se chama na língua materna Boe de Kiogoaro ${ }^{20}$, ilustrado na Figura 4. Ressalta-se que cada pena colocada no kiogoaro lembra as aves que são propriedade de cada sub clã.

Figura 4 - Adorno do sub clã Apiboregue pertencente à metade Tugarege

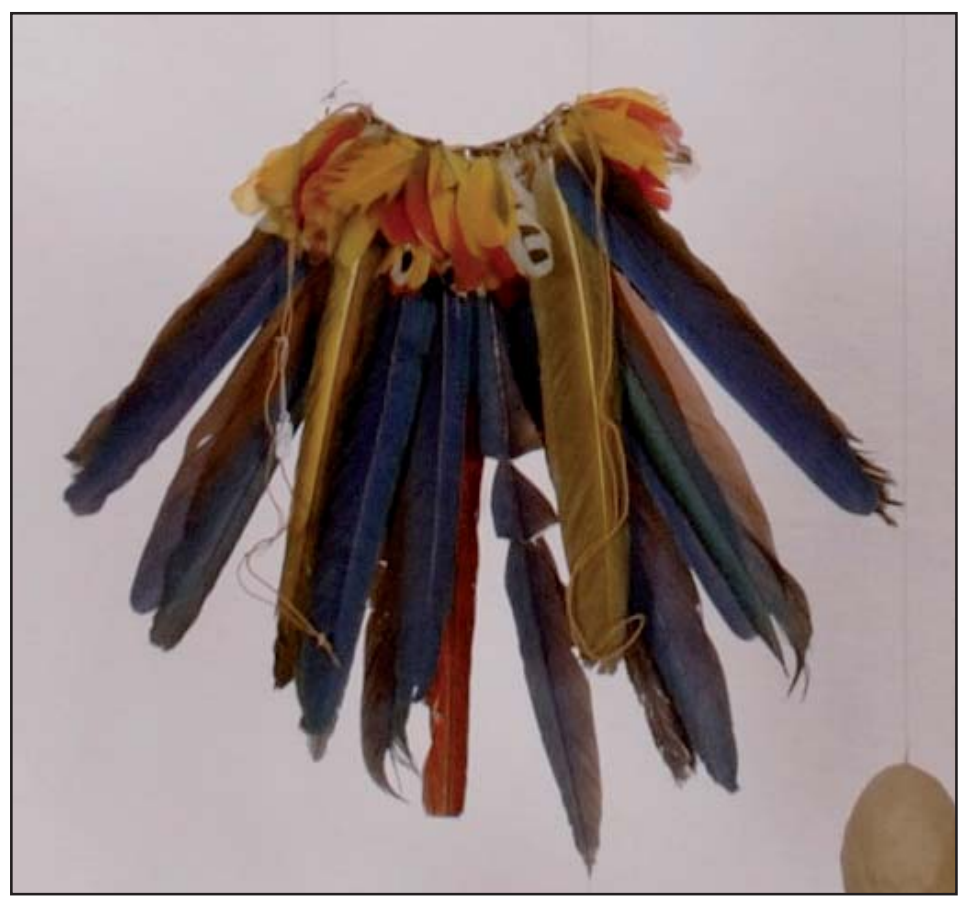

Fonte: Adaptado de Calarge (2013).

\footnotetext{
${ }^{20}$ Enfeites de penas que atado na cabeça, pende do occipício sobre as costas. É usado principalmente por crianças e mulheres; em certas representações é usado também como bracelete e adornos de objetos rituais tais como Ke (rede ritual), Mano (roda de talos de caeté), Marido (roda de talos de folhas de buriti), Kado Raireu (taquara comprida) e de arcos.
} 
Os kiogoaro dos demais sub clãs, bem como os demais adornos, podem ser consultados no artigo de Calarge (2013), o qual relata a exposição museográfica realizada sobre a Cultura Bororo. A seguir, serão informadas as características sobre os tipos de penas utilizados na constituição do kiogoaro de cada sub clã.

\subsubsection{Características do Clã dos Ecerae}

a) Baadojeba (Sub Clã dos construtores de aldeias): Ciwabo Oiaga 'cauda de xexéu', Korao Oiaga 'cauda de papagaio verdadeiro', Nabure 'arara vermelha', Kuido 'arara amarela', Barugi 'pequeno gavião'.

b) Kie (Sub Clã cujo principal símbolo é a anta): Kudoro 'arara azul', Ciwabo 'xexéu'.

c) Bokodori Ecerae (Sub Clã cujo o símbolo é o tatu canastra): Nabure (só se usa pena vermelha).

d) Bakoro Ecerae (Sub Clã presidido pelos chefes Akaruio Boroge $e^{21} e$ Mamuiawuge Eceba ${ }^{22}$ ): Iwe Oto 'espinhos de ouriço cacheiro', Nabure Oiaga 'cauda de arara vermelha', Kuido 'arara amarela'.

\subsubsection{Características do Clã dos Tugarege (Tugo arege)}

a) Paiowe (Sub Clã cujo símbolo é o bugio chamado de pai): Piabo Oiaga 'cauda de surucuá', Kudoro 'pena azul e amarela', Meriri 'metal', Nabure Aro 'peninhas interiores da raiz da asa da arara vermelha', Kuido aro 'peninhas interiores da raiz da asa da arara amarela', Kuido Bu 'plumagem de arara amarela', Nabure $B u$ 'plumagem de arara vermelha'.

b) Apiborege (Sub Clã dos Apido arege, donos da palmeira acuri): Kurugugwa Oiaga Manoreu (centro da cauda do Gavião Caracaraí), Nabure 'arara vermelha', Kuido 'arara amarela'.

c) Iwagudo (Sub Clã que tem como símbolo principal a gralha azul): Jakomea Atugo (peitoral pintado, nome próprio do Iwagudo): pena vermelha de arara, Kurugugwa Oiaga (centro da cauda do gavião caracarai), Mokureabo Agareu

\footnotetext{
${ }^{21}$ Chefe dos Boroge - o nome Boroge é uma variedade de marandová, lagarta.

22 Célebre antepassado do sub clã dos Bakoro Ecerae. Mamuiawuge (os belos, os bonitos, os Bororo), Eceba (matador, inimigo, adversário, encarregado).
} 
Oiaga 'tipo de prego ornamental encimado por duas penas de cauda de curiango', Piodudo brado 'cauda comprida de beija-flor verdadeiro'.

d) Aroroe (Plural de aroro, clã que tem como símbolo a larva de borboleta: tem a cabeça vermelha e o corpo listrado de faixas amarelas e pretas): Bakuguma Oiaga 'tipo de prego ornamental dos Bororo, feito com uma pena de cauda de gavião requinta', Korao Oiaga 'centro da cauda do papagaio verdadeiro', Bakoro Atugo 'pena preta e vermelha'.

Na descrição apresentada, é possível observar que cada sub clã Bororo é possuidor de um certo tipo de penas de aves e elas pertencem a esse sub clã. $O$ que é comum a todos os clãs são as plumagens das araras, e o que diferencia um clã do outro são algumas aves particulares a cada sub clã, ou seja, a maioria tem as penas de arara mas, em especial, possuem uma ave que é privativa a seu clã. É isso que diferencia os clãs e seus enfeites.

\subsection{Restrições alimentares}

O Povo Bororo tem uma relação muito boa com os animais na sua prática alimentícia e cultural, dependem deles como alimento e também são necessários na prática social. De acordo com Calarge (2017), a dieta alimentar dos Bororo é rica em animais e plantas, nativas ou cultivadas na região em que se encontra a etnia. Segundo a autora, na região orarimogodoge (dos peixes pintados), é abundante a quantidade de mamíferos, aves e peixes, como o pacu.

Conforme os dados coletados no estudo, quando um caçador mata um certo tipo de animal e quando as pessoas o veem chegando da caça, pegam alguma coisa de valor para poder trocar com a caça trazida pelo caçador à aldeia. Esse ato de troca faz com que a aldeia seja beneficiada com coisas que talvez a casa de algumas famílias não tenha, por isso, há essa reciprocidade do dar e receber algo de alguém da comunidade.

Na nossa fauna, há alguns animais que os Bororo não utilizam como alimento devido aos ensinamentos que thes foram repassados outrora, pelos antepassados. Alguns animais que os Bororo não fazem o uso na sua alimentação sem serem oferecidos e benzidos pelo Bari (Pajé) são: Ki 'anta', Uwai 'jacaré', Akiwa 'capivara', e o Pobogo 'veado campeiro', Jugo 'queixada', Atubo 'veado galheiro', Bacieje 'veado catingueiro', Pari 'ema', Beo 'seriema'. Para que os Bororo possam 
se alimentar desses animais, eles necessitam passar pelas pajelanças de um Pajé, denominado "Bari"23 pelos Bororo. Ele é o sacerdote da aldeia, o que cura os males espirituais, o que está em constante sintonia com o espiritual, o que desvia da aldeia todos os perigos como tempestades, doenças, o benzedor de crianças e jovens, e também afasta os espíritos do mal da aldeia.

Atualmente, os Bororo sofrem com a ausência desse sábio que contribui muito para comunidade, visto que a pessoa que é o Bari da aldeia é uma pessoa que tem um dom vindo do mundo Espiritual, e cabe a ele aceitar, ou não, o chamado dos espíritos.

Segundo a tradição desse povo, existem alguns animais que os Bororo não fazem uso como alimento, e esse costume vem de outrora, pelos seus antepassados. Alguns desses animais que são o Pobogo 'veado', ki 'anta' e o okiwa 'capivara'. Alguns peixes que os bororo são proibidos de utilizar como alimento são: poru 'jaú', orarije 'surubim', kidokia 'pirarara', ou seja, segue o mesmo raciocínio do kare paru.

Segundo o consultor nativo, esses conhecimentos vêm de antigamente, e são transmitidos de geração em geração. De acordo com suas palavras: "Nós não se alimenta porque os nossos antepassados nos passaram isso para nós e, hoje, a gente come pelo fato de não ter mais o bari" (Joaquim Toroa).

O fato de os Bororo não terem mais o Bari entre eles provocou mudanças em algumas situações, como por exemplo, em relação às doenças que a comunidade irá ter, pois ele tinha o poder de desviar seu povo dos males espirituais. Por intermédio do Bari que os Bororo eram protegidos no que se refere ao espiritual, doenças, mal feitos, jorubo pegareu ${ }^{24}$, entre outros.

Enfim, o Bari tem um papel muito importante dentro da sociedade Bororo; para ser Bari o Bororo tem que ter uma inspiração, um dom, um chamado ou uma vocação. Atualmente, tem-se a ausência desse personagem religioso, os Bororo esperam que surja alguma pessoa inspirada para exercer tal função dentro da comunidade.

${ }^{23}$ É o curandeiro da aldeia, é ele quem afasta os males, benze as crianças e jovens, benze os animais para os Bororo se alimentarem deste animal.

${ }^{24}$ Doença ruim. 
Esses resultados revelam a intensa relação entre os Bororo e os animais, tanto para a cultura, para a alimentação, como para a organização social. Nos estudos de Razera, Boccardo e Pereira (2006), envolvendo estudantes Tupinambá, a importância dos animais para aquela etnia está atrelada à utilidade (fonte de alimentos, vestuário e serviço), ao aspecto afetivo e à questão mística e espiritual, o que não difere dos Bororo que acentuam ainda mais essa relação.

\section{CONSIDERAÇÕES FINAIS}

A riqueza de um povo está nas suas origens, nos seus mitos que nortearão o seu convívio e regras sociais. Muitas vezes, questiona-se o porquê de alguns hábitos sem considerar que as justificativas para a existência deles estão nas origens, nos mitos. A divisão tradicional dos mamíferos, aves e peixes e outros seres da natureza, tem norteado os Bororo no que diz respeito aos seus cantos, artesanatos (adornos originais), pinturas e nomes.

As propriedades de cada sub clã Bororo é que orientarão e enriquecerão muitas situações dentro dos rituais sagrados, dos enfeites e dos nomes que eles têm direito de utilizar nos seus batizados, na cultura.

A riqueza do Povo Bororo está na sua cultura, que é riquíssima de conhecimento e sabedoria e, muitas vezes, surgem questionamentos cujos detalhes, entendimentos e essências precisam ser buscados lá no fundo das raízes culturais. Se esse questionamento não for feito, corre-se o risco de fazer a prática sem conhecer seus fundamentos, outrora deixados pelos Bororo, para seguir uma organização social e cultural religiosa.

Esta pesquisa é apenas um fragmento de uma cultura riquíssima a ser estudada, e que as reflexões aqui apresentadas sirvam para ver os mamíferos, os répteis, os anfíbios, os peixes e as aves com um outro olhar, o olhar que os Bororo tiveram e norteou-os na organização de suas regras sociais e culturais.

\section{REFERÊNCIAS}

ANGROSINO, M. Etnografia e observação participante. Porto Alegre: Artmed, 2009. (Coleção Pesquisa Qualitativa).

ALBISETTI, C.; VENTURELLI, A. J. Enciclopédia Bororo. Campo Grande: Museu Regional Dom Bosco, 1962. v. 1 e 2. 
BARROS, E. P. de; BORDIGNON, M. Jarudori - estudos e levantamentos prévios históricoantropológicos. Relatório relativo ao Termo de Referência DAF/DEID n. 53/2002, do Departamento de Identificação e Delimitação da Diretoria de Assuntos Fundiários/FUNAI. Brasília, DF, 2003.

CALARGE, C. F. C. A metáfora museográfica da organização social Bororo no Museu das Culturas Dom Bosco. Tellus, Campo Grande, MS, ano 13, n. 25, p. 217-29, jul./dez. 2013.

CALARGE, C. F. C. O olhar das crianças bororo sobre a cultura: desenhos infantis e representação. Tellus, Campo Grande, MS, ano 17, n. 32, p. 165-75, jan./abr. 2017.

GIL, A. C. Métodos e técnicas de pesquisa social. 6. ed. São Paulo: Atlas 2010.

GRANDO, B. S. Educação da criança indígena e educação infantil em Mato Grosso: uma questão para o debate. Tellus, Campo Grande, MS, ano 16, n. 31, p. 81-95, jul./dez. 2016.

ISAAC, P. A. M. Modo de existir Terena na comunidade multiétnica que vive em Mato Grosso. 2004. Tese (Doutorado em Ciências Sociais)- Pontifica Universidade Católica de São Paulo. São Paulo, SP, 2004.

JANUÁRIO, E. Caminhos da fronteira. Cáceres, MT: Unemat Editora, 2004.

MINAYO, M. C. de S. Pesquisa social: teoria, método e criatividade. 27. ed. Petrópolis: Vozes, 2008.

OCHOA CAMARGO, G. História mítica Bororo [versão em língua portuguesa]. Campo Grande: UCDB, 2010. v. 2.

RAZERA, J. C. C.; BOCCARDO, L.; PEREIRA, J. P. R. Percepções sobre a fauna em estudantes indígenas de uma tribo tupinambá no Brasil: um caso de etnozoologia. Revista Electrónica de Enseñanza de las Ciencias - REEC, v. 5, n. 3, p. 466-80, 2006.

RIBEIRO, D. O povo brasileiro: a formação e o sentido de Brasil. 2. ed. São Paulo: Companhia das Letras, 1995.

SOUZA, L. A. de. Bakaru na comunidade indígena bororo da Aldeia Central de Tadarimana, em Rondonópolis-MT: conceitos e manifestações. 2014. Tese (Doutorado em Educação) - Universidade Federal de Minas Gerais, Belo Horizonte, MG, 2014.

SOUZA, L. G. de; PAGLIARO, H.; SANTOS, R. V. Perfil demográfico dos índios Boróro de Mato Grosso, Brasil, 1993-1996. Cadernos de Saúde Pública (FIOCRUZ), Rio de Janeiro, v. 25, n. 2, p. 328-36, 2009. 


\section{Sobre os autores:}

Cézar Amin Rondon: Graduação em Ciências Matemáticas e da Natureza, pela Faculdade Intercultural Indígena, Universidade do Estado de Mato Grosso (UNEMAT). Professor Indígena da Rede Estadual SEDUC/MT, município de Rondonópolis, Mato Grosso, Brasil. E-mail: cezar_rondon@yahoo.com.br

Marcelo Franco Leão: Doutorando em Educação em Ciências na Universidade Federal do Rio Grande do Sul (UFRGS). Mestre em Ensino pela Universidade do Vale do Taquari (UNIVATES). Especialização em Orientação Educacional na Dom Alberto e em Relações Raciais na Educação e na Sociedade Brasileira pela Fundação Universidade Federal de Mato Grosso (UFMT). Graduação em Licenciatura em Química na Universidade de Santa Cruz do Sul (UNISC) e em Física (UNEMAT). Orientador na Faculdade Indígena Intercultural da UNEMAT. Professor do Departamento de Ensino do Instituto Federal de Mato Grosso (IFMT) Campus Confresa. Membro do Grupo de Pesquisa Ensino de Ciências e Matemática no Baixo Araguaia (EnCiMa). E-mail: marcelo.leao@cfs.ifmt.edu.br

Recebido em 10 de fevereiro de 2018

Aprovado para publicação em 17 de maio de 2018 